\title{
Yield of tomato fruits in relation to silicon sources and rates
}

\author{
Josué C Marodin'; ${ }^{1}$ Juliano TV Resendeㄹ; Rafael GF Morales²; Maria LS Silva ${ }^{3}$; Alexandre G Galvão \\ Daniel S Zanin ${ }^{1}$ \\ 'UNICENTRO, C. Postal 3010, 85040-080 Guarapuava-PR; josuemarodin@hotmail.com; jvresende@uol.com.br; zanin.suek@hotmail. \\ com; ${ }^{2}$ EPAGRI, C. Postal 277, 88318-112 Itajaí-SC; moralescefet@yahoo.com.br; ${ }^{3}$ UFLA, C. Postal 3037, 37200-000 Lavras-MG; \\ marialigia.silva@dcs.ufla.br; galvao.alexandre@hotmail.com
}

\begin{abstract}
There is controversy about the benefits of silicon ( $\mathrm{Si}$ ) on tomato plants. This element has structural and metabolic functions in the physiology of plants, generating benefits that may result in increased productivity of various plant species. Thus, the aim of this study was to evaluate the phytotechnical characteristics and the productivity of tomato plants according to the rates and sources of Si. The design was established in randomized blocks with factorial $3 \times 5$, corresponding to three sources of silicate (calcium silicate, potassium silicate and sodium silicate) and five doses of Si (equivalent to 0, 100, 200, 400 and $800 \mathrm{~kg} \mathrm{ha}^{-1}$ of $\mathrm{SiO}_{2}$ ). The fertilization with $\mathrm{Si}$ increased the commercial productivity of tomato plants and reduced the occurrence of cracked fruits. Calcium and potassium silicates increased the $\mathrm{Si}$ levels on the leaves linearly with the increase of the doses, while sodium silicate reduced the levels in larger doses. Silicon fertilization increases the productivity of tomato plants with possible economic return on the use of this input.
\end{abstract}

Keywords: Solanum lycopersycum, cracked fruits, potassium silicate, calcium silicate, silicon fertilization.

\begin{abstract}
RESUMO
Produtividade do tomateiro em função de fontes e doses de silício

Há controvérsias sobre os benefícios do silício (Si) no tomateiro. Este elemento possui funções estruturais e metabólicas sobre a fisiologia das plantas, gerando benefícios que podem resultar no aumento da produtividade de várias espécies vegetais. Assim, o objetivo foi avaliar características fitotécnicas e a produtividade do tomateiro em função de doses e fontes de Si. O delineamento foi em blocos casualizados em fatorial 3 x 5 , correspondendo a três fontes de silicato (silicato de cálcio, silicato de potássio e silicato de sódio) e cinco doses de $\mathrm{Si}$ (equivalentes a 0, 100, 200, 400 e $800 \mathrm{~kg} \mathrm{ha}^{-1}$ de $\mathrm{SiO}_{2}$ ). A adubação com $\mathrm{Si}$ aumentou a produtividade comercial do tomateiro e reduziu a ocorrência de frutos rachados. Os silicatos de cálcio e de potássio aumentaram os teores de Si nas folhas linearmente com o aumento das doses, enquanto o silicato de sódio reduziu os teores nas maiores doses. A adubação silicatada aumenta a produtividade do tomateiro com possibilidade de retorno econômico na utilização desse insumo.
\end{abstract}

Palavras-chave: Solanum lycopersycum, frutos rachados, silicato de potássio, silicato de cálcio, adubação silicatada.

\section{(Recebido para publicação em 28 de maio de 2013; aceito em 26 de março de 2014) (Received on May 28, 2013; accepted on March 26, 2014)}

$\mathrm{T}$ omato is one of the most demanding vegetables in nutrients and responds to high doses of chemical fertilizers (Fayad et al., 2002). Considering the mineral nutrition, 14 mineral elements are essential for the plants (Epstein \& Bloom, 2006) and some elements are considered beneficial, because the lack of these elements is not considered a limiting factor to the normal growth and development of the plants. Among them, is silicon $(\mathrm{Si})$, which has structural and metabolic functions in the plant physiology, generating numerous benefits which may result in the increase of the productivity of several plant species (Korndörfer \& Datnoff, 1995; Carvalho et al., 2002; Lana et al., 2003; Almeida et al., 2009).

The beneficial effects of Si have been related to the tolerance to various biotic and abiotic stresses, such as salinity (Zhu et al., 2004), toxicity caused by zinc excess (Ramos et al., 2009), transpiration (Hattori et al., 2005) penetration and development of fungal hyphae (Ma \& Yamaji, 2006) stresses by high and low temperatures (Ma \& Yamaji, 2006). Moreover, the adequate nutrition with $\mathrm{Si}$ interferes in the plant architecture, by providing more erect leaves, increasing solar radiation interception and photosynthetic efficiency (Pereira et al., 2003; AlAghabary et al., 2004).

The ability of Si accumulation in tissues varies among species, which may be classified into accumulator $(>4 \% \mathrm{Si})$, intermediate $(2-4 \% \mathrm{Si})$ and non-accumulators of $\mathrm{Si}(<2 \%$
Si) (Ma \& Yamaji, 2006). Generally, the accumulator species, such as the grasses (Poaceae), can increase the productive yield, promoting various desirable physiological and biochemical processes for plants (Hunt et al., 2008). The Si-non-accumulator species, such as the tomato (Lana et al., 2003), need more researches to improve the understanding of the physiological responses of the crop to Si fertilization.

In tomato, the addition of $\mathrm{Si}$ in the standard nutrient solution improved calcium concentrations in leaves and fruits, reducing the occurrence of blossom-end rot (Carvalho et al., 2002; Stamatakis et al., 2003), altered the metabolism of leaves exposed to salt stress (Al-Aghabary et al., 2004) and increased the total number of fruits and 
the productivity as the availability of Si in the soil (Fiori, 2006). Regarding pests and diseases, the application of Si reduced in approximately 50\% the number of injuries caused by thrips (Frankliniella schultzei) (Almeida et $a l ., 2009$ ) and in 56.2\% the incidence of bacterial wilt (Ralstonia solanacearum) (Dannon \& Wydra, 2004).

The calcium silicate $\left(\mathrm{CaSiO}_{3}\right)$, potassium silicate $\left(\mathrm{K}_{2} \mathrm{SiO}_{3}\right)$ and sodium silicate $\left(\mathrm{Na}_{2} \mathrm{SiO}_{3}\right)$ have variable $\mathrm{SiO}_{2}$ solubility and availability. The benefits of the use of silicates are not always attributed to $\mathrm{Si}$, such as the increase of soil $\mathrm{pH}$, reduction of toxic aluminum $\left(\mathrm{Al}^{+3}\right)$, increase of soil base saturation, increase of exchangeable $\mathrm{Ca}$ and $\mathrm{Mg}$ and increase of phosphorus availability (Korndörfer et al., 2002).

Although the results found in the literature confirm the benefits of $\mathrm{Si}$ for tomato, few studies highlighted if these benefits reflect an increase of productivity. Also, the lack of information about the best sources and doses of Si restrict the researches to clarify the mode of action of $\mathrm{Si}$ in the plant. Thus, the goal of this study was to evaluate the productivity of tomatoes related to doses and sources of Si and their effects on phytotechnical characteristics.

\section{MATERIAL AND METHODS}

The experiment was carried out from October 2009 to March 2010, in Guarapuava, Paraná state, Brazil, with the tomato cultivar Kada Gigante, of Santa Cruz group, which has the following characteristics: indeterminate growth habit, cycle between 180 and 250 days, average mass of fruits of $130 \mathrm{~g}$, low post-harvest conservation and high susceptibility to the disruption of the fruit epicarp. The local climate is $\mathrm{Cfb}$, Köppen classification, characterized as subtropical, mesothermal and humid, without definite dry season. The average annual rainfall is $1944 \mathrm{~mm}$, annual average minimum temperature of $12.7^{\circ} \mathrm{C}$, annual average maximum temperature of $23.5^{\circ} \mathrm{C}$ and relative humidity of $77.9 \%$ (Thomaz \& Vestena, 2003).
The pots were filled with soil classified as Bruno Latosol distrophic (Embrapa, 2006), clayey texture, sieved through a $4 \mathrm{~mm}$ mesh and homogenized. The soil chemical analysis showed the chemical characteristics: $\mathrm{pH}\left(\mathrm{CaCl}_{2}\right)=$ $5.0 ;$. organic matter $=37.6 \mathrm{~g} \mathrm{dm}^{-3} ; \mathrm{P}$ (Mehlich) $=1.1 \mathrm{mg} \mathrm{dm}^{-3} ; \mathrm{K}, \mathrm{Ca}, \mathrm{Mg}$, $\mathrm{Al}, \mathrm{H}+\mathrm{Al}$ and $\mathrm{CTC}$, respectively $=$ $0.1,3.4,1.9,0,5.3,11 \mathrm{cmol}_{\mathrm{c}} \mathrm{dm}^{-3}$. The concentrations of $\mathrm{B}, \mathrm{Cu}, \mathrm{Fe}, \mathrm{Mn}$ and $\mathrm{Zn}$ were $0.23,1.00,129.00,43.20$ and 1.40 $\mathrm{mg} \mathrm{dm}{ }^{-3}$, respectively. The $\mathrm{Si}$ content in the soil extracted with $\mathrm{CaCl}_{2} 0.01 \mathrm{~mol}$ $\mathrm{L}^{-1}$ was $11 \mathrm{mg} \mathrm{dm}^{-3}$.

The experimental design was of randomized blocks, with four replications, with four pots and one plant per pot in each plot. The treatments were arranged in a $3 \times 5$ factorial, corresponding to three sources of silicate [calcium silicate $\left(\mathrm{CaSiO}_{3}\right)$, potassium silicate $\left(\mathrm{K}_{2} \mathrm{SiO}_{3}\right)$ and sodium silicate $\left.\left(\mathrm{Na}_{2} \mathrm{SiO}_{3}\right)\right]$ and five doses of $\mathrm{Si}$ (equivalent to $0,100,200,400$ and $800 \mathrm{~kg} \mathrm{ha}^{-1}$ of $\mathrm{SiO}_{2}$ ). Silicates, applied in the form of salts, were added to soil to a depth of $5 \mathrm{~cm}$ and $5 \mathrm{~cm}$ from the base of the plant, fractioning each dose in three applications: before seedling transplanting, early flowering and during fruiting, on the occasion of issuing the fifth raceme. To nullify the effect of the accompanying ions $(\mathrm{Ca}, \mathrm{K}$ and $\mathrm{Na})$ of silicates, together with the other treatments were applied calcium chloride, potassium chloride and sodium chloride fertilizers, such that all treatments were given the same quantities of these elements $\left(229 \mathrm{~kg} \mathrm{ha}^{-1}\right.$ $\mathrm{CaO}, 361 \mathrm{~kg} \mathrm{ha}^{-1} \mathrm{~K}_{2} \mathrm{O}$ and $229 \mathrm{~kg} \mathrm{ha}^{-1}$ of $\mathrm{Na}_{2} \mathrm{O}$ ).

The seedlings were grown in polystyrene trays of 128 cells containing Plantmax ${ }^{\circledR}$ substrate. Thirty five days after sowing, when the seedlings showed two pairs of expanded leaves and about $5 \mathrm{~cm}$ high, these seedlings were transplanted to $7 \mathrm{~L}$ capacity pots.

The pots were kept in a protected environment, spaced at $1.0 \mathrm{~m}$ between lines and 0.4 between plants. The planting fertilization was calculated based on soil analysis, using urea, potassium chloride and triple superphosphate, totaling 300 $\mathrm{kg} \mathrm{ha}^{-1} \mathrm{~N}, 200 \mathrm{~kg} \mathrm{ha}^{-1} \mathrm{~K}_{2} \mathrm{O}$ and $300 \mathrm{~kg}$ $\mathrm{ha}^{-1}$ of $\mathrm{P}_{2} \mathrm{O}_{5}$. The soil base saturation was adjusted to $80 \%$, by applying $3500 \mathrm{~kg} \mathrm{ha}^{-1}$ of dolomitic limestone. Eight side dressing fertilizations were done weekly, starting one month after transplanting the seedlings to pots, totalizing doses equivalent to $200 \mathrm{~kg} \mathrm{ha}^{-1}$ of $\mathrm{N}$ and $300 \mathrm{~kg} \mathrm{ha}^{-1}$ of $\mathrm{K}_{2} \mathrm{O}$ (Alvarenga et al., 2004).

Plants were conducted with one stem, tutored weekly in vertical trellis system, and apical pruning above the third leaf was carried out after the seventh raceme. A drip irrigation system with a water depth of $5 \mathrm{~mm}$ day $^{-1}$ was used to irrigate the plants daily. The pest control (triflumuron, $250 \mathrm{~g} \mathrm{~kg}^{-1}, 15 \mathrm{~g}$ a.i. $100 \mathrm{~L}^{-1}$ of water, acephate, $750 \mathrm{~g} \mathrm{~kg}^{-1}$, 100 g p.c. $100^{-1} \mathrm{~L}$; pymetrozine, 500 $\mathrm{g} \mathrm{kg}^{-1}, 40$ g p.c. $100^{-1} \mathrm{~L}$ ) and diseases (copper oxychloride, $250 \mathrm{~g}$ a.i. $100 \mathrm{~L}^{-1}$ of water, mancozeb + metalaxyl-m, 300 g p.c. $100^{-1} \mathrm{~L}$; azoxystrobin, 16 g p.c. $100 \mathrm{~L}^{-1}$ of water; thiamethoxam $750 \mathrm{~g}$ $\mathrm{kg}^{-1}, 20 \mathrm{~g} 100^{-1} \mathrm{~L}$ of water; chlorothalonil $720 \mathrm{~g} \mathrm{~L}^{-1} 126 \mathrm{~g}$ a.i. $100 \mathrm{~L}^{-1}$ of water) was done weekly, alternating the products mentioned.

The fruits were harvested weekly, starting the harvest from the eleventh week after transplanting. For commercial fruit productivity, all the fruits with commercial standard were counted and weighed $\left(\mathrm{t} \mathrm{ha}^{-1}\right)$ of each plot and, then, the occurrence of cracked fruits was determined $\left(\mathrm{t} \mathrm{ha}^{-1}\right)$. During the productive period, samples of five marketable fruits and ten leaves per plot were weighed and dehydrated in an oven with forced air circulation at a constant temperature of $70^{\circ} \mathrm{C}$, until constant weight was reached. The dry mass of the leaves and fruits was determined by the percentage of dry mass (\%).

The leaf silicon was quantified in a sample of a leaf per plant, collecting the first leaf above the first cluster, according to the methodology described by Silva \& Vale (2007). Due to sampling be performed during fructification of the first cluster, in order to avoid negative effects on the productivity of the fruits, just one leaf per plant was used. The samples were dehydrated until they reached constant mass, in an oven with forced air circulation at temperature of $70^{\circ} \mathrm{C}$. The determination of Si content was performed using the methodology 
described by Korndörfer et al. (2004), with values expressed in $\mathrm{g} \mathrm{kg}^{-1}$ of dry mass of leaves.

Data were subjected to analysis of variance and polynomial regression, and the $\mathrm{R}^{2}$ values of the regression equations tested by $\mathrm{F}$ test. The coefficient $\mathrm{r}$ (Pearson) was determined, tested by the $t$ test $(5 \%)$, in order to establish correlations between the analyzed factors.

\section{RESULTS AND DISCUSSION}

An effect only of doses on commercial fruit productivity, fruit dry mass, leaf dry mass and number of cracked fruits was observed. For $\mathrm{Si}$ content in the leaves, an influence of the interaction between doses and sources was noticed.

The fertilization with $\mathrm{Si}$ increased the commercial productivity of tomato plants to $401 \mathrm{~kg} \mathrm{ha}^{-1}$ of $\mathrm{SiO}_{2}$ with an estimated productivity of $60.8 \mathrm{t} \mathrm{ha}^{-1}$ (Figure 1a). From this dose, a reduction on the productivity was observed. Probably, because of the nutritional imbalance caused by $\mathrm{Si}$ or by the accompanying ions (calcium, potassium and sodium) that compete for the same absorption sites of other nutrients (Korndörfer et al, 2002; Fernandes $\&$ Souza, 2006). These results are in accordance with those observed by Fiori (2006), in which the application of basic slag, as source of $\mathrm{Si}$, promoted an increase in the total number of fruits and productivity. This fact was attributed to the increased availability of $\mathrm{Si}$ in the soil. The increase of the productivity of the tomato plants at the dose of 401 $\mathrm{kg} \mathrm{ha}^{-1}$ of $\mathrm{SiO}_{2}$ can be attributed to the benefit effects of $\mathrm{Si}$ in the plant, as an improve of the architecture for showing more erect leaves, which intercept higher solar luminosity increasing the photosynthetic efficiency (Pereira et al., 2003) and higher chlorophyll content (Braga et al., 2009). However, these results cannot be attributed to the reduction of damage caused by pests and diseases and reduction of water stress, because these factors were controlled in this experiment. Several authors did not observe differences in the productivity of tomato plants when the Si availability to the plants was increased (Lana et al., 2003; Pereira et al., 2003; Pereira \& Vitti, 2004). For Pereira et al. (2003) the absence of significant results was due to high initial Si contents in the soil, which contributed to minimize the effects of Si on production.

Besides increasing the commercial productivity of fruits, fertilization with Si decreased the occurrence of cracked fruits, that means, non-commercial fruits, with better response at a dose of $505 \mathrm{~kg} \mathrm{ha}^{-1}$ of $\mathrm{SiO}_{2}$ (Figure 1b). The main cause of the disturbance is the rapid influx of solutes and water in the fruit, usually at the time of ripening, when the strength and elasticity of the skin are reduced (Kinet \& Peet, 1997) and the pressure of the locule is incremented (Almeida \& Huber, 2001), occurring tiny cracks, expanding thereafter during ripening. Lana et al. (2003) observed that in a soil with no

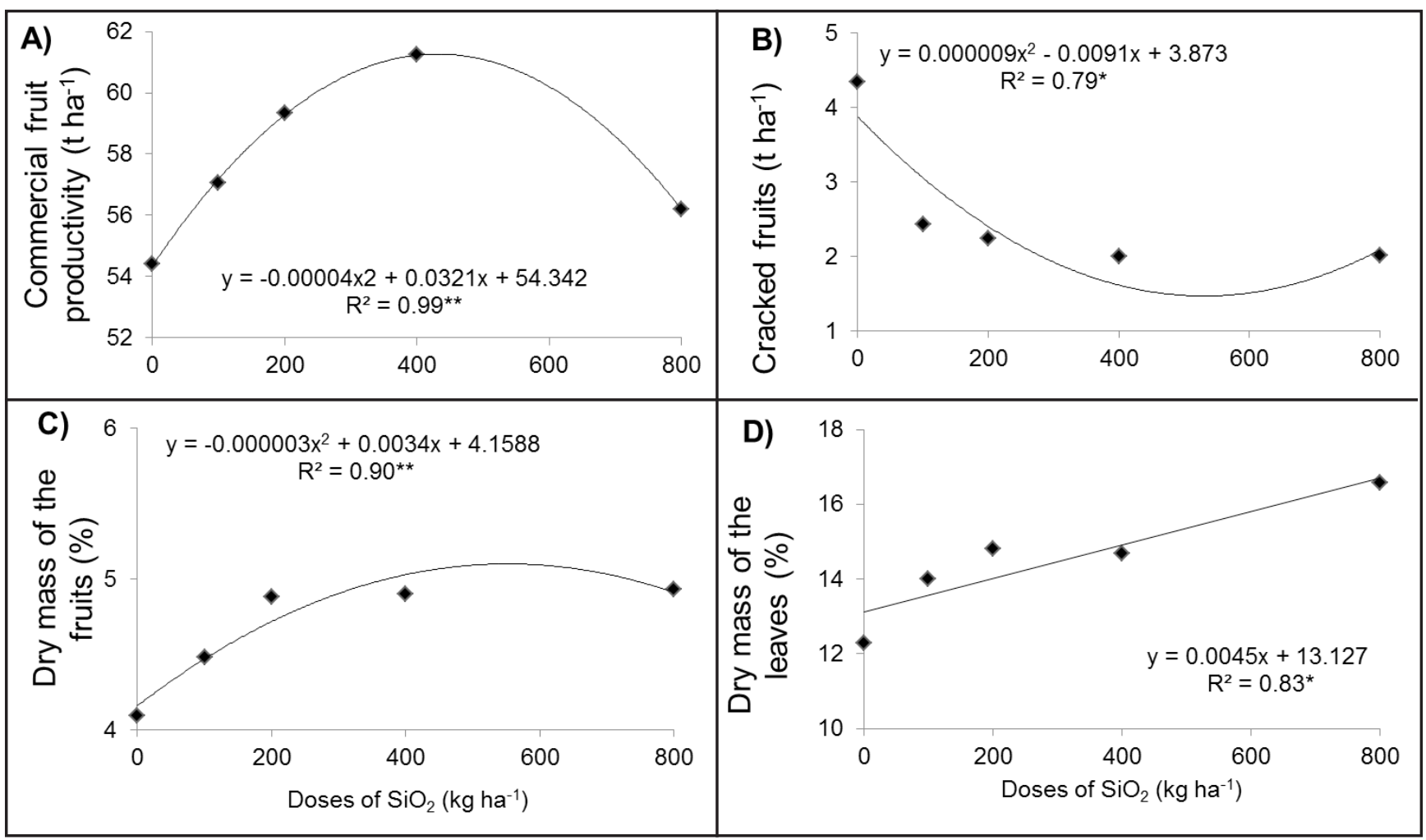

Figure 1. Fertilization doses on total fruit yield (a), cracked tomato fruits (b), dry mass of fruits (\%) (c) and leaves (d) of tomato. *and**= $\mathrm{p} \leq 0.05$ and $\mathrm{p} \leq 0.01$, respectively (adubação com doses de $\mathrm{SiO}_{2}$ sobre a produtividade de frutos comerciais (a) e de frutos rachados (b), percentagem de massa seca de frutos (c) e de folhas (d) do tomateiro. $\mathrm{e}^{* *=} \mathrm{p} \leq 0,05$ e $\mathrm{p} \leq 0,01$, respectivamente). Guarapuava, UNICENTRO, 2010. 


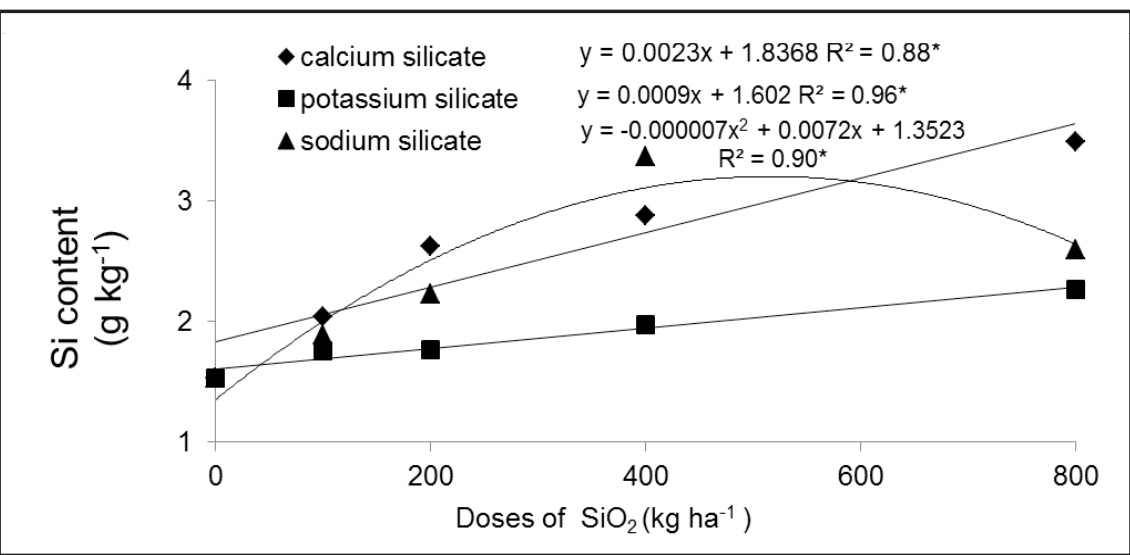

Figure 2. Silicon content of tomato leaves after application of three silicon sources in soil. *and $* *=p \leq 0.05$ and $p \leq 0.01$, respectively (teor de silício nas folhas do tomateiro em função de três fontes de silício aplicadas via solo. $*^{* *}=p \leq 0,05$ e $p \leq 0,01$, respectivamente). Guarapuava, UNICENTRO, 2010.

silicon fertilization, the productivity of commercial tomato fruits was 40.1 $\mathrm{t} \mathrm{ha}^{-1}$ and non-commercial was $26.6 \mathrm{t}$ $\mathrm{ha}^{-1}$. However, when the calcium silicate was applied at the dose of $4000 \mathrm{~kg} \mathrm{ha}^{-1}$, the commercial productivity increased to $56.0 \mathrm{t} \mathrm{ha}^{-1}$ and non-commercial reduced to $15.1 \mathrm{t} \mathrm{ha}^{-1}$, this values being statistically not different. The authors attributed the results to the beneficial effects of Si, mainly due to the increase of the mechanical strength of the cell wall.

The calcium and potassium silicates increased the Si content in the leaves linearly, with maximal response at the highest dose $\left(800 \mathrm{~kg} \mathrm{ha}^{-1}\right.$ of $\left.\mathrm{SiO}_{2}\right)$, with contents of $3.49 \mathrm{~g} \mathrm{~kg}^{-1}$ and $2.27 \mathrm{~g} \mathrm{~kg}^{-1}$ of $\mathrm{Si}$, respectively (Figure 2). In contrast, the sodium silicate provided maximum response $\left(3.2 \mathrm{~g} \mathrm{~kg}^{-1}\right)$ at a dose equivalent to $514 \mathrm{~kg} \mathrm{ha}^{-1}$ of $\mathrm{SiO}_{2}$, reducing its values in larger doses. The increase of $\mathrm{Si}$ content in the leaf in smaller doses of sodium silicate occurs due to greater solubility in water of this source, which favors absorption (Moraes et al., 2006). The increase of $\mathrm{Si}$ content in the tomato leaf ( 1.84 to $\left.3.39 \mathrm{mg} \mathrm{kg}^{-1}\right)$ was also observed by Pereira \& Vitti (2004) after the schist application $(52 \%$ of $\mathrm{Si})$ in the soil, showing that the tomato crop absorbs this nutrient according to the higher availability in the soil.

The fruit dry mass (MSFru) increased $20 \%$ in the dose of $566 \mathrm{~kg} \mathrm{ha}^{-1}$ of $\mathrm{SiO}_{2}$ in relation to the control, reducing from this dose (Figure 1c). In contrast, the leaf dry mass (MSFol) increased linearly up to the highest doses of $\mathrm{Si}$, an increase of $25 \%$ (Figure 1d). The increase in absorption of $\mathrm{Si}$ and, consequently, the increase of its concentration in the leaf, explains the increase of $92 \%$ for MSFru and the increase of $88 \%$ for MSFol, by correlation analysis. The highest values of MSFru and MSFol in response to doses of $\mathrm{Si}$ are probably related to the action of this element in cell metabolism. The Si increases the photosynthetic efficiency of the plant, resulting in greater accumulation of solids in leaf tissues (Pereira et al., 2003; Al-Aghabary et al., 2004). These photoassimilates can be translocated to the fruits, which are strong metabolic drains (Peluzio et al., 1999); it may be one of the factors responsible for the increase in the productivity.

With the increase in the productivity to approximately $6.4 \mathrm{tha}^{-1}$ of the tomato obtained at the estimated dose of $401 \mathrm{~kg}$ $\mathrm{ha}^{-1}$ of $\mathrm{SiO}_{2}$, the estimated gross financial return would be $\mathrm{R} \$ 7,300.00 \mathrm{ha}^{-1}$, if one takes into account the average price of $\mathrm{R} \$ 1.15 \mathrm{~kg}^{-1}$ obtained in the last eight months in Ceasa of Belo Horizonte (Ceasaminas, 2012). However, taking into account the calcium silicate $(22.4 \%$ of $\mathrm{SiO}_{2}$ and $34.9 \%$ of $\mathrm{CaO}$ ), deducting the amount of R $\$ 146.45 \mathrm{ha}^{-1}$ by 400 $\mathrm{kg}$ of $\mathrm{SiO}_{2}$ and the average cost of $\mathrm{R} \$$ $900.00 \mathrm{ha}^{-1}$ on the use of this input, similar to management adopted in this experiment, net economic return would be $\mathrm{R} \$ 6,253.60 \mathrm{ha}^{-1}$, without considering shipping. The calcium silicate, besides having low cost, has low solubility, which assures the gradual and continuous supply of nutrients. Moreover, potassium and sodium silicates, sources of high solubility, when applied to the soil at high doses, can cause nutritional imbalance, damaging the soil and the plant.

Thus, the authors concluded that the fertilization with $\mathrm{Si}$ increases the tomato productivity and, consequently, the economic return of the crop. However, more studies under field conditions are necessary, in other soils and with other tomato cultivars in order to recommend or include this element in the fertilization of this crop.

\section{REFERENCES}

AL-AGHABARY K; ZHU Z; SHI QH. 2004. Influence of silicon supply on chlorophyll content, chlorophyll fluorescence, and antioxidative enzyme activities in tomato plants under salt stress. Journal of plant nutrition 27: 2101-2115.

ALMEIDA DPF; HUBER DJ. 2001. Transient increase in locular pressure and occlusion of endocarpic apertures in ripening tomato fruit. Journal of Plant Physiology 158: 199-203.

ALMEIDA GD; PRATISSOLI D; ZANUNCIO JC; VICENTINI VB; HOLTZ AM; SERRÃO JE. 2009. Calcium silicate and organic mineral fertilizer increase the resistance of tomato plants to Frankliniella schultzei. Phytoparasitica 37: 225-230.

ALVARENGA MAR; LIMA LA; FAQUIN V. 2004. Fertirrigação. In: ALVARENGA MAR (ed). Tomate: produção em campo, em casade-vegetação e em hidroponia. Lavras: Editora UFLA. p.121-158.

BRAGA FT; NUNES CF; FAVERO AC; PASQUAL M; CARVALHO JGD; CASTRO EMD. 2009. Características anatômicas de mudas de morangueiro micropropagadas com diferentes fontes de silício. Pesquisa Agropecuária Brasileira 44: 128-132.

CARVALHO JDG; MACHADO AQ; ASCIMENTO IRD; BOAS RCV. 2002. Desempenho da cultura do tomate adubado com silifértil. Horticultura Brasileira 20: 402.

CEASAMINAS - Centrais de Abastecimento de Minas Gerais. 2012, 25 de setembro. Preços e ofertas. Disponível em http://www. ceasaminas.com.br.

DANNON EA; WYDRA K. 2004. Interaction between silicon amendment, bacterial wilt development and phenotype of Ralstonia solanacearum in tomato genotypes. Physiological and Molecular Plant Pathology 64: 233-243

EMBRAPA. 2006. Centro Nacional de Pesquisa de Solos (Rio de Janeiro, RJ). Sistema 
brasileiro de classificação de solos. Brasília: Embrapa-SPI. 306p.

EPSTEIN E; BLOOM AJ. 2006. Nutrição mineral de plantas: Principios e perspectivas. Londrina: Planta. 403p.

FAYAD JA; FONTES PCR; CARDOSO AA; FINGER FL; FERREIRA FA. 2002. Absorção de nutrientes pelo tomateiro cultivado sob condições de campo e de ambiente protegido. Horticultura Brasileira 20: 90-94.

FERNANDES MS; SOUZA SR. 2006. Absorção de nutrientes. In: FERNANDES MS (ed). Nutrição mineral de plantas. Viçosa: SBCS.

FIORI MP. 2006. Comportamento de cultivares de tomateiro quanto à utilização de escórias siderúrgicas em ambiente protegido. 54. (Tese doutorado).

HATTORI T; INANAGA S; ARAKI H; AN P; MORITA S; LUXOVA M; LUX A. 2005. Application of silicon enhanced drought tolerance in Sorghum bicolor. Plant Physiology 123: 459-466.

HUNT JW; DEAN AP; WEBSTER RE; JOHNSON GN; ENNOS AR. 2008. A novel mechanism by which silica defends grasses against herbivory. Annals of Botany 102: 653-656.

KINET JM; PEET MM. 1997. Tomato. In: WIEN HC (ed). The physiology of vegetable crops. Wallingford: $\mathrm{CAB}$ International.
KORNDÕRFER GH; DATNOFF LE. 1995. Adubação com silício: uma alternativa no controle de doenças da cana-de-açúcar e do arroz. Info. Agronômicas 70: 1-3.

KORNDÖRFER GH; PEREIRA HS; CAMARGO

MS. 2002. Silicatos de cálcio e magnésio na agricultura. Boletim técnico 1:24. Uberlândia: GPSi/ICIAG/UFU.

KORNDÖRFER GH; PEREIRA HS; NOLLA A. 2004. Análise de silício: solo, planta e fertilizante. Boletim técnico 2: 34. Uberlândia: GPSi-ICIAG-UFU.

LANA RMQ; KORNDÖRFER GH; ZANÃO JUNIOR LA; SILVA AFD; LANA AMQ. 2003. Efeito do silicato de cálcio sobre a produtividade e acumulação de silício no tomateiro. Bioscience Journal 19: 15-20.

MA JF; YAMAJI N. 2006. Silicon uptake and accumulation in higher plants. Trends in Plant Science 11: 342-397.

MORAES SRG; POZZA EA; ALVES E; POZZA AAA; CARVALHO JG; LIMA PH; BOTELHO AO. 2006. Efeito de fontes de silício na incidência e na severidade da -antracnose do feijoeiro. Fitopatologia Brasileira 31: 69-75.

PELUZIO JM; CASALI VWD; LOPES NF; MIRANDA GV; SANTOS GR. 1999. Comportamento da fonte e do dreno em tomateiro após a poda apical acima do quarto cacho. Ciência Agrotécnica 23: 510-514.

PEREIRA HS; VITTI GC. 2004. Efeito do uso do xisto em características químicas do solo e nutrição do tomateiro. Horticultura Brasileira 22: $317-322$

PEREIRA HS; VITTI GC; KORNDÖRFER GH. 2003. Comportamento de diferentes fontes de silício no solo e na cultura do tomateiro. Revista Brasileira de Ciência de Solo 27: 101-108.

RAMOS JS; CASTRO EMD; CARMO PINTO SID; FAQUIN V; OLIVEIRA CD; PEREIRA GC. 2009. Uso do silício na redução da toxidez de zinco em mudas de eucalipto. Interciencia 34: 189-194.

SILVA DJH; VALE FXR. 2007. Tomate: Tecnologia de produção. Viçosa: UFV.

S TAMATAKIS A; SAVVAS D ; PAPADANTONAKIS N; KEFALAS PNLS. 2003. Effects of silicon and salinity on fruit yield and quality of tomato grown hydroponically. Acta Horticulturae 609: 141-149.

THOMAZ EL; VESTENA LR. 2003. Aspectos Climáticos de Guarapuava-PR. Guarapuava: UNICENTRO.

ZHU ZJ; WEI GQ; LI J; QIAN QQ; YU JQ. 2004. Silicon alleviates salt stress and increases antioxidant enzymes activity in leaves of saltstressed cucumber (Cucumis sativus). Plant Science 167: 527-533. 